Фіалковський А.P.

\title{
АЛГОРИТМ ФОРМУВАННЯ РЕГІОНАЛЬНОЇ СИСТЕМИ ПІДТРИМКИ ІННОВАЦІЙНОГО ПІДПРИЕМНИЦТВА
}

\begin{abstract}
Показано значення системи підтримки інноваційного підприємництва як фактору конкурентоспроможності регіональної економіки. Окреслені імперативи функціонування системи підтримки, до яких віднесено стратегічні, оперативні принципи, а також системні імперативи, тобто таки, що дозволяють ефективно функціонувати як в умовах стратегічного, та й оперативного управління. Виділені наступні кроки алгоритму формування системи підтримки інноваційного підприємництва: етап креативної філософії, перспективного аналізу, проектування; крок практичної організації, етап функціонування та контролінгу.
\end{abstract}

Ключові слова: інноваційне підприємництво, розвиток, конкурентоспроможність, підтримка інноваційного підприємництва, система, принципи, алгоритм.

Постановка проблеми. Інноваційне підприємництво в сучасних умовах постає як життєве необхідне явище, розвиток якого $\epsilon$ стратегічною регіональною метою. Активізація інноваційного підприємництва виступає важливим фактором формування високого рівня конкурентоспроможності регіону, будучи імпульсом 3 багатовекторним та мультиплікативним ефектом забезпечує розвиток виробничої та торгівельної сфер, покращує інвестиційну привабливість регіону, формує його імідж як території 3 інноваційними перспективами, розвиває ринок освітніх послуг, при цьому підвищує якість освіти в регіоні через формування специфічних кадрових потреб, обумовлює необхідність створення інфраструктури відтворення висококваліфікованої робочої сили, формує певну регіональну культуру, змінює якість життя.

Для створення відповідних умов функціонування інноваційного підприємництва існує широке коло методів та важелів на різних рівнях економіки, але в умовах Закарпаття результати проведеного аналізу дозволяють стверджувати, що методи, механізми та суб'єкти повинні отримати підтримку на системній основі.

Це підтверджує необхідність формування системи підтримки інноваційного підприємництва в Закарпатській області.

Аналіз останніх досліджень і публікацій. Проблематика інноваційного підприємництва залучає увагу широкого кола вітчизняних та закордонних науковців. Серед останніх публікацій доцільно виділити праці словацького

(C) Фіалковський А.P., аспірант кафедри економіки i підприємництва, ДВНЗ «Ужгородський національний університет», тел:+380675052367 економіста Е. Хвіздової (Е.,Hvizdová, 2014), яка доводить, що інновації та технології представляють фактор формування високого рів-ня конкурентних переваг економічної системи [1, c.32] та разом 3 Б. Блоговою у подальших дослідженнях показує значення креативних індустрій та інновацій у економічному розвитку [2] (E.,Hvizdová, B. Blogová, 2016).

Братиславські дослідники (Kroslakova М., Kubichkova V., Jurkovichova L., 2015) розглядають значення інновацій для так званих «газелей» - підприємств, що мають високі обороти швидкості економічного розвитку і які «make up an important part of enterprises of all compared countries, and they contribute significantly to competitiveness of given economies. [3, 27].

Колектив науковців Інституту економіки та прогнозування НАН України (2016) звертає увагу на перевагах та ризиках у інноваційні активності вітчизняних підприємств, що несе інтеграція економіки України у європейській простір, підкреслюючи, що «важливим напрямом взаємодії України та ЄС є діяльність у науковотехнічній та інноваційній сфері. Угода зможе прискорити процеси розповсюдження високих технологій та загальної модернізації національної економіки України. Водночас слід зазначити, що на шляху реалізації цього завдання існує значна кількість проблем, в першу чергу інституційного характеру. Стан розвитку високих технологій та інноваційної діяльності залишається складним, в окремих секторах спостерігаються негативні тенденції, пов'язані зі скороченням фінансування досліджень і розробок, зменшенням загальних обсягів виробництва, експансією зарубіжних конкурентів». [5, 22]

Закарпатські апологети теорій інноваційного розвитку (Мошак С.М., Мікловда В.П. та ін., 2017) роблять акцент на стратегічному управлінні 
новаторським венчурним бізнесом, підкреслюючи його перспективність ризикованість: «Розвиток інноваційного підприємництва, який створює ринок праці для креативних, мобільних, інноваційно спрямованих працівників. Як вже було відмічене, інноваційне підприємництво буде ефективним за умови розбудови регіональної інноваційної системи, яка спрямована не лише на перетворення знань у інновації, але $\epsilon$ платформою підготовки та використання мотивованих на розвиток працівників. Таким чином, інноваційноінвестиційний потенціал та потенціал людський є взаємообумовленими та взаємодоповнюючими». [8, с.150].

Визначають «здатність галузевого виробництва до інноваційного розвитку залежно від вибраного стратегічного напряму» I. Ю. Салькова, І. В. Ковальчук, Л. Б. Петіна (2016) в процесі розвитку аграрного сектору економіки. [7, с.29].

Провідний фахівець у проблематиці національних інноваційних систем Грига В. (2010) приділяє увагу обструкціям, що стоять на шляху впровадження НIC в Україні, стверджуючи, що «хоча сьогодні в Україні й сформовано основні елементи НІС, суттєвою проблемою залишається встановлення та забезпечення системних взаємозв' язків між ними. Крім цього, недостатньо використано можливості технологічного навчання, що має стати предметом державної політики у сфері інноваційної та науково-технологічної діяльності. Подальший розвиток НIC України повинен насамперед передбачати розвиток інноваційної інфраструктури, зокрема офісів трансферу технологій, та інших організацій, що сприятимуть налагодженню зв'язків між підприємствами й науковими установами». [4, с.33-34].

3 позиції кадрового забезпечення інноваційної активності як умови конкурентоспроможності економічної системи підходить Череп О.Г., стверджуючи, що в сучасних умовах кадровий потенціал слід розглядати як сукупні можливості i здібності працівників, необхідних для здійснення дій, що забезпечують стратегічну перевагу серед конкурентів [9].

Разом 3 тим, вказані науковці не охоплюють дослідженнями практичні шляхи підвищення ефективності інноваційного бізнесу та ігнорують роль регіональних організацій в активізації підприємницької інноваційної активності. Залишається поза увагою організаційноекономічні важелі активізації інноваційного підприємництва, що гальмує побудову системної конкурентоспроможності.
Формулювання цілей статті. Метою даної статті $€$ обгрунтування основних етапів формування системи підтримки інноваційного підприємництва на рівні регіону як умови формування його радикальних конкурентних переваг.

Для досягнення мети вирішені завдання:

1. Висвітлені принципи, на яких будується система активізації інноваційного підприємництва.

2. Розкрито зміст та послідовність основних етапів створення системи підтримки інноваційного бізнесу в Закарпатській області.

В процесі написання роботи були використані таки методи наукового дослідження як монографічний при вивченні сучасних поглядів на підприємництво та його новаторський тип; системний, що сприяє комплексному підходу до окреслення шляхів розвитку та підтримки інноваційного підприємництва в регіоні; діалектичний - в процесі обгрунтування послідовності кроків формування системи підтримки інноваційного підприємництва.

Опис основного матеріалу дослідження. Система підтримки інноваційного підприємництва (СПIП) Закарпаття як каталізатор процесів в регіоні спрямована на реалізацію наступної мети: забезпечення середовища, в якому ефективно та взаємоузгоджене будуть діяти механізми підтримки новаторської підприємницької активності, спрямованої на розвиток регіональної економіки та формування пii конкурентних переваг. «В сучасних умовах кадровий потенціал слід розглядати як сукупні можливості і здібності працівників, необхідних для здійснення дій, що забезпечують стратегічну перевагу серед конкурентів» СПІП Закарпаття базується на дотриманні наступних імперативів, які поділені на три групи:

А. Стратегічні, тобто таки, що забезпечують реалізацію мети створення та функціонування СПІП, а також характеризують іiі взаємодію 3 суб'єктами інноваційного підприємництва та поведінку в навколишньому оточенні.

Б. Системні, що сприяють роботі всій СПІП та ii елементів. Необхідність дотримання даних принципів обумовлена методологічним вибором системного підходу до підтримки інноваційного підприємництва, в межах якого сама система представляє живій організм, діяльність якого залежить від узгодженої роботи всіх складових.

B. Принципи, які визначають якість оперативного функціонування СПІП Закарпаття (ефективність, оптимальність, динамічність).

Алгоритм створення СПІП Закарпаття рекомендовано наступний (рис.1.). 


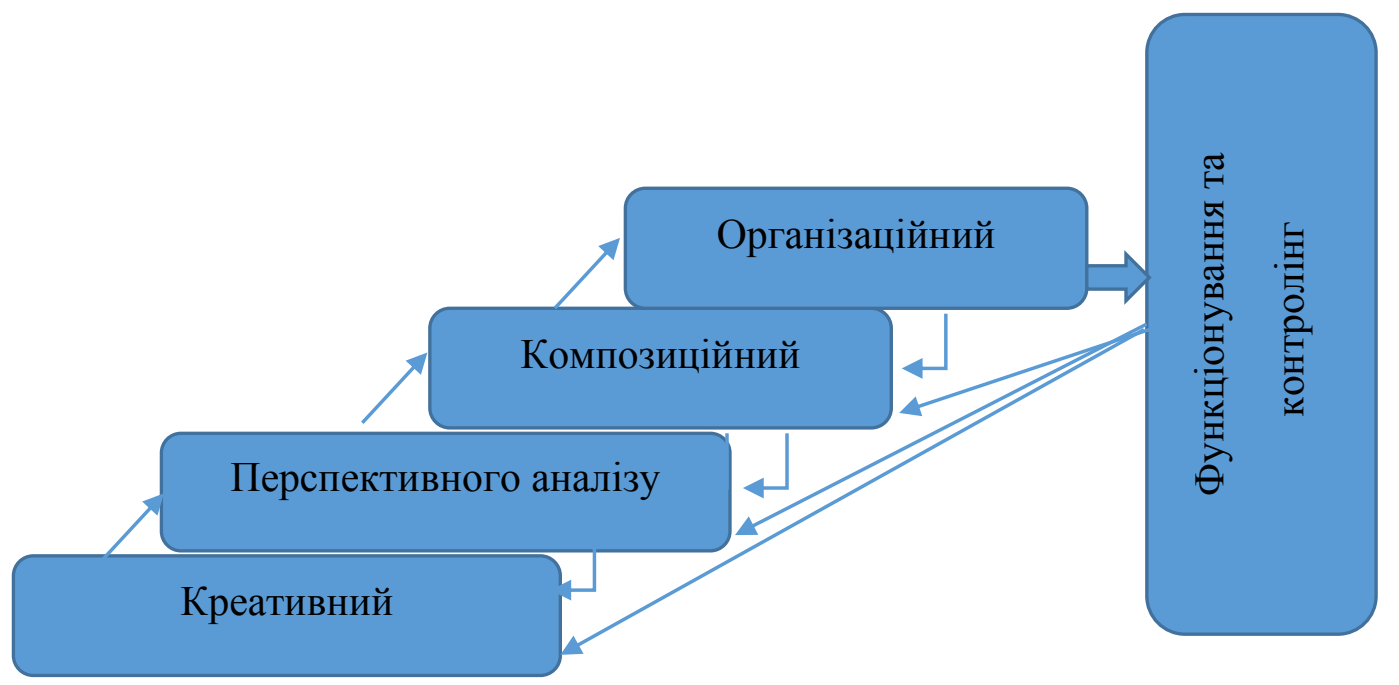

*складено автором

Рис.1. Етапи формування СПІП Закарпатської області*

1. Етап креативної філософії формування СПІП Закарпаття. На даному етапі відбувається СПІП, принципів іiі функціонування та завдань). Стадія креативної філософії дозволяє зрозуміти місце даного регіону в системі національних та глобальних відносин, розвернути дискусію в регіональному соціумі по визначенню бачення на перспективи регіонального розвитку. На даному етапі здійснюється одна 3 базових функцій стратегічного управління економічними системами - цілепокладання, яка формує вектори та орієнтири довгострокового функціонування організаційної структури

2. На другому етапі проводиться стратегічний аналіз можливих компонентів СПІП Закарпаття з їх функціями та місцем в архітектурі Системи підтримки. Виявляються основні фактори зовнішнього середовища Системи та чинники внутрішні, які можуть оказати суттєвий вплив на Систему та їі поведінку. Проводиться позиціювання регіону відносно його інноваційного потенціалу як базового елементу Системи. Особливого значення на даному етапі набуває каузально-індукційний аналіз, який визначає наслідки певних функцій в роботі СПІП. Каузальна індукція «визначена як метод пізнання, що грунтується на формально-логічному виводі, який дає можливість одержати загальний висновок на основі окремих фактів. При застосуванні каузальної індукції можуть мати місце ефекти подібності, специфічності та ін., які дозволяють забезпечити аналітиків сучасним інструментарієм економічної оцінки господарських явищ». [10, с.107 ] Причинонаслідковий аналіз в сукупностями 3 традиційними методами стратегічного визначення загальної ідеї та формування методологічних основ функціонування (мети дослідження дозволяє на даному етапі виявити ключові аспекти інноваційного підприємництва та базові елементи СПІП. Стратегічний аналіз сприяє окресленню можливостей та обмежень, сильних та слабких сторін інноваційного підприємництва в регіоні. В залежності від вибору методу аналізу існує можливість визначення політичних, технологічних, економічних та соціальних факторів та їх вплив на інноваційне підприємництво в Закарпатті.

3. Стадія композиції системи. В процесі проектування СПІП Закарпаття як достатньо складної системи доцільно використати модульний метод. Модуль представляє собою групу елементів системи або окремий її елемент, що, виступаючи відкритою системою, характеризуються наявністю власних, притаманних лише даному модулю входів та виходів. Модуль також характеризується ознакою цілісності. Наприклад, модуль 3 умовною назвою К (кадровий потенціал СПІП) характеризується входами та виходами: вхід ззовні СПІП, тобто зовнішній вплив на модуль К або його елементи; вплив компонентів, модулів чи елементів СПІП, до якої належить модуль К; вихідний імпульс, вихідний вплив модуля К на зовнішнє оточення СПІП; вихідний ефект, вплив модуля К на інші елементи СПІП.

Для СПІП Закарпаття виділені таки модулі як: інформаційно-консалтинговий функціями інформаційної та консалтингової підтримки інноваційного підприємництва) ;

- $\quad$ фінансовий (метою є фінансовий супровід інноваційного підприємництва); 
- науковий (формуючий наукову базу майбутніх інновацій)

$$
\text { - кадровий }
$$

функціонування

(забезпечуючий регіонального ринку праці та його адекватність потребам інноваційного підприємництва);

- маркетинговий (метою модуля $\epsilon$ формування іміджу регіону та просування продукції регіонального інноваційного підприємництва на національному та світовому ринках);

інституційний ( відповідальний за норми взаємовідносин між модулями, а також 3 регіональним оточенням, інноваційну культуру, довіру між суб'єктами інноваційної активності та їх контрагентами з інших сфер).

контролінговий (виконуючий функції аналізу проблем та перспектив регіонального інноваційного підприємництва, забезпечуючи при цьому систему підтримки інформацією для прийнятяя адекватних стратегічних управлінських рішень).

4. Фаза практичної організації представляе собою найбільш важливий етап проектування СПІП Закарпаття внаслідок того, що саме від організаційних дій залежить якість функціонування Системи. Функція організації полягає у окресленні внутрішніх інституційних норм СПІП та їх узгодження 3 інституційними нормами регіонального та національного рівнів. Встановлюється координація дій та ефектів модулів СПІП. Формується культура взаємовідносин як частина регіональної культури підтримки інновацій. Доцільно «інноваційну культуру розглядати як системне явище, яке представляє собою сукупність інноваційних та культурник складових, що взаємодіють між собою і викликають появу нових благ та їх якостей, що в свою чергу $є$ основою розвитку суспільства та його економічної сфери». [6, с. 26]

Важливою складовою $є$ впровадження довіри, яка набуває економічного сенсу та певних управлінських якостей. Довіра знижує рівень трансакційних витрат, що є одним зі способів керування ризиками інноваційної діяльності. Крім цього, довіра сприяє часу узгодження договорів, слугує методом профілактики конфліктів та досягнення консенсусу в процесі договірної діяльності, що суттєво зменшує час на підготовку та прийняття управлінських рішень.

5. Етап функціонування та контролінгу.

Фактично даний етап знаходиться поза межами проектування, але вважаємо за доцільне виділяти його з метою підкреслення необхідності фидбеку СПІП та окреслення функцій й методів контролінгу, який надає інформацію про роботу системи і забезпечує менеджмент даними про виконання управлінських рішень. На етапі функціонування особливого звучання набуває інформаційна система, яка не лише містить мережу, але й забезпечує учасників Системи повною та своєчасною інформацією.

Висновки та перспективи подальших досліджень. Система підтримки інноваційного підприємництва забезпечує створення мережі взаємодії підприємництва, інфраструктури та суб'єкту стратегічного управління регіоном.

Якість та спрямованість СПІП Закарпаття залежить від дотримання імперативів функціонування, які в даному досліджені поділені на три групи: стратегічні; системні, оперативні.

Алгоритм формування Системи підтримки інноваційного підприємництва Закарпатської області містить наступні кроки: креативної філософії, в русі якого відбувається визначення загальної ідеї та формування методологічних основ іiі функціонування; перспективного аналізу, в наслідок якого окреслюється загальний контур та компонентна будова СПIП; проектування Системи дозволяє виділити конкретні модулі з їх функціями та взаємодією; крок практичної організації спрямований на визначення та формування внутрішніх інституційних норм СПІП та їх узгодження з інституційними нормами регіонального та національного рівнів, встановлюється координація дій та ефектів модулів СПІП, а також створюється культура взаємовідносин як частина регіональної культури підтримки інновацій; етап функціонування та контролінгу, метою якого є забезпечення Системи об'єктивною та достовірною інформацією про поведінку системи.

У подальшому дослідженні заплановано побудувати модель системи підтримки інноваційного підприємництва в регіоні.

\section{ПЕРЕЛІК ВИКОРИТАНИХ ДЖЕРЕЛ}

1. Hvizdova E. (2016) Changes in research and development after crisis in selected countries / E. Hvizdova, V. Mokrisova, J. Polacko // Economic Annals. - 160(7-8), 2016. - P. 31-34.

2. Hvizdová E. CREATIVE INDRUSTRY OF SELECTED HANDICRAFTS IN EASTERN SLOVAKIA/ E. Hvizdová,

B. Blogová - Mainz : Logophon Verlag GmbH,2016. ISBN 978-3936172-47-8. 2,4 AH

3. Kroslakova M., Kubichkova V., Jurkovichova L., Kubiniy N. Dynamics of high growth enterprises - "gazelles" - in Check Republic. Problems and Perspectives in Management. 2015. Vol. 13. Issue 2. P. 27-35. 
4. Грига В. Особливості формування національних інноваційних систем / В. Грига // Вісник Національної академії наук України. - 2009. - № 10. - С. 22-35. - Режим доступу: http://nbuv.gov.ua/UJRN/vnanu_2009_10_3.

5. Імплементація Угоди про асоціацію між Україною та $Є С$ : економічні виклики та нові можливості: наукова доповідь/за ред. акад В.М. Гейця та чл.-кор. НААН України Т.О. Осташко. - ДУ ІЕПр НАН України . - 2016. $184 \mathrm{c}$.

6. Кубіній В. В. Сучасні концепти інноваційної культури / В. В. Кубіній // Науковий вісник Ужгородського університету. Серія : Економіка. - 2017. - Вип. 2. - С. 23-27. - Режим доступу: http://nbuv.gov.ua/UJRN/Nvuuec_2017_2_4.

7. Салькова І.Ю. Теоретичні основи інновацйного розвитку АПК України /Салькова І.Ю., Ковальчук І.В . Петіна Л.Б.// Агросвіт - 2016 - №7 - pC.27-31,

8. Стратегічне управління конкурентоспроможністю: системний метод та екзистенціальна експозиція: монографія / [Мошак С.М., Мікловда В.П., Шандор Ф.Ф., Кубіній Н.Ю., Кубіній В.В.] - Мукачево: Карпатська вежа. $-2017 .-240 \mathrm{c}$.

9. Череп О.Г. Управління кадровим потенціалом підприємств машинобудування Запорізької області / О.Г. Череп, І.О. Гайдай // Збірник матеріалів XI Міжнародної науковопрактичної конференції: "Виклики та перспекти ви розвитку нової економіки на світовому, державному та регіональному рівнях" / За заг. ред. А.В. Череп. Запоріж жя: Видавництво ЗНУ - 2016. - С. 273-274.

10. Югас Е.Ф. Каузальна індукція в аналізі та моделюванні економічних процесів / Югас Е.Ф. , Туряниця К.С. // Науковий вісник Ужгородського університету. Серія: Економіка - 2013 - Вип. 4 (41). - С.103-107

\section{REFERENCES}

1. Hvizdova, E. (2016) Changes in research and development after crisis in selected countries. Economic Annals, 160(78), 31-34 [in English].

2. Hvizdova, E. (2016). Creative indrustry of selected handicrafts in eastern Slovakia. Mainz: Logophon Verlag GmbH, 2, 4 [in English].

3. Kroslakova, M., \& Kubichkova, V., \& Jurkovichova, L., \& Kubiniy, N. Dynamics of high growth enterprises "gazelles" - in Check Republic. Problems and Perspectives in Management. 2015. Vol. 13. Iss. 2, $27-35$ [in English].

4. Gryga, V. (2009) Osoblyvosti formuvannya nacional'nyh innovacijnyh system [Features of the formation of national innovation systems]. Visnyk Nacional'noyi akademiyi nauk Ukrayiny - Bulletin of the National Academy of Sciences of Ukraine, Iss. 10, 22-35 [in Ukranian].

5. Gejc, V. \& Ostashko, T. (Eds.) (2016). Implementaciya Ugody pro asociaciyu mizh Ukrayinoyu ta YeS: ekonomichni vyklyky ta novi mozhlyvosti: naukova dopovid ' Implementation of the Association Agreement between Ukraine and the EU: Economic Challenges and New Opportunities: Scientific Report] [in Ukraine].

6. Kubiniy, V. (2017). Suchasni koncepty innovacijnoyi kul'tury [Modern concepts of innovation culture]. Naukovyj visnyk Uzhgorods`kogo universytetu -Scientific Bulletin of UzhNU, Iss. 2, 23-27 [in Ukranian].

7. Sal'kova, I. \& Koval'chuk I. \& Petina L. (2016). Teoretychni osnovy innovacjnogo rozvytku APK Ukrayiny [Theoretical basis of innovation development of ACC of Ukraine]/ Agrosvit - Agroworld, 7, $27-31$ [in Ukranian].

8. Moshak, S., \& Miklovda, V., \& Shandor F., \& Kubiniy N.., \& Kubiniy V. (2017). Stratehichne upravlinnia konkurentospromozhnistiu: systemnyi metod ta ekzystentsialna ekspozytsiia: monohrafiia [Strategic Management of Competitiveness System Method and Existenal Exposition]. Mukachevo: Karpatska vezha [in Ukranian] .

9. Cherep, O., \& Gaigay I. (2016). Upravlinnya kadrovym potencialom pidpryyemstv mashynobuduvannya Zaporiz koyi oblasti [Management of personnel potential of engineering enterprises of Zaporizhzhya region]. Vyklyky ta perspektyvy rozvytku novoyi ekonomiky na svitovomu, derzhavnomu ta regional'nomu rivnyah. Proceedings of the International Scientific Conference. Zaporizhzhya: ZNU, 273-274 [in Ukranian].

10. Yugas, E., \& Turyanycya, K. (2013). Kauzal'na indukciya v analizi ta modelyuvanni ekonomichnyh procesiv [Causal Induction in Analysis and Modelling of Economic Process]. Naukovyj visnyk Uzhgorods`kogo universytetu - Scientific Bulletin of UzhNU, Iss. 4 (41), 103-107 [in Ukranian].

Одержано 12.02.2019 